УДК 37.015.31:616-084:364-787.26]005.941(477+438)

DOI: $\underline{10.35619 / \mathrm{iiu} . \mathrm{v} 2 \mathrm{i} 13.365}$

Larysa Slyvka

Candidate of Pedagogical Sciences, Ph.D.,

Associate Professor at the Department of Primary Education Pedagogy

Vasyl Stefanyk Precarpathian National University,

Ivano-Frankivsk, Ukraine

ORCID: 0000-0003-1865-6326

e-mail:loroczka@ukr.net

Nataliia Koturbash

Applicant for Higher Education the Second ("Master's) Degree in

Specialty Primary Education

Vasyl Stefanyk Precarpathian National University,

Ivano-Frankivsk, Ukraine

ORCID: 0000-0002-4654-6274

e-mail: nataliia.koturbash@pnu.edu.ua

\title{
PUBLIC INITIATIVES IN IMPLEMENTATION HEALTHCARE EDUCATIONAL PROGRAMS: UKRAINIAN AND POLISH EXPERIENCE
}

\begin{abstract}
The article attempts to make an analytical section on the practice of implementing in Ukraine and Poland some educational programs aimed at forming a healthy lifestyle of children and youth, in particular the role of public activists and organizations in this process.

The activity of public organizations and societies, which in the 1920s 1930s carried out health care activities in Western Ukraine is summarized. There are represented Polish institutions which at the end of $19^{\text {th }}-$ at the beginning of the $220^{\text {th }}$ century took part in the organization of the public movement to promote health among the population. Two health projects implemented in modern Ukraine are mentioned: "Anti-addiction campaign against alcohol, tobacco and drug use among schoolchildren in IvanoFrankivsk" (2009) and "Youth for a healthy lifestyle" (2016). The list of Polish educational programs is presented, in which various health-preserving content is presented ("Glass of milk", "Keep fit", "Clean air around us", "Fruits and vegetables at school", "Healthy food and physical activity in schools", "Don't fall for me, please", "Running for health", "Safe road to school", "I click with my head"). It is noted that public figures and organizations contribute to the dissemination of positive information about certain projects, provide financial support, etc.
\end{abstract}

Keywords: health education, educational programs, public activities, Ukraine, Poland.

(C) Larysa Slyvka,

Nataliia Koturbash, 2021 


\section{Інноватика у вихованні. Випуск 13.Том 2. 2021.}

Problem statement. The health of the individual and the nation as a whole is considered in civilized countries as the highest social value and a powerful factor in the socio-economic development of the state. Therefore, much attention is paid to improving the health care system, implementing various prevention initiatives and health education. At the same time, the health indicators of children and young people, according to statistical sources (Zdrowie i zachowania zdrowotne młodzieży szkolnej w Polsce, 2015), remain disappointing. In this context, the relevance of the topic declared in the title of the article is not denied and is due to the need to study effective approaches to the formation of a healthy lifestyle of a growing individual and the implementation of educational programs of appropriate content.

Research publications analysis. This issue is actively studied by Ukrainian scientists, as evidenced by a number of defended dissertations (O. Vashchenko, O. Zhabokrytska, S. Kondratyuk, S. Omelchenko, S. Svyridenko, T. Shapovalova, S. Yurochkina, etc.) and numerous fundamental works on issues of formation of positive motivation for a healthy lifestyle of children and youth (L. Omelchenko, O. Omelchenko, V. Orzhekhovska, T. Osadchenko, etc.). Meanwhile, among the scientific research of today there are very few complex works, which represent the theoretical, methodological and practical principles of health education programs for children and youth, implemented in Ukraine and abroad, and describe the «public» factor in their implementation.

So the purpose of the article is an attempt to conduct a certain analytical section on the practice of implementing in Ukraine and Poland some educational programs aimed at shaping a healthy lifestyle of children and youth, in particular the role of public activists and organizations in this process.

Presenting the main research material. First of all, we note that an important condition for the effectiveness of health-preserving educational influences is the continuity of this process. It is provided by subject-institutional partnership and is manifested in the appropriate interaction of a large number of subjects of education (teachers, psychologists, parents, health workers, others) and social institutions - educational and out-of-school educational institutions, family environment, cultural and educational institutions, children-youth associations, public organizations, etc. (Kondratyuk, 2003, p. 9).

The public sector has always been in the path of various movements related to the health of the population of a country in general and children and youth in particular. For example, in the 1920s and 1930s, there were a number of public organizations and societies in Western Ukraine that, under the conditions of stateless development of Ukrainians, took on the "lion's" share of care for the health of the region's inhabitants, namely in Galicia - "Health Cooperatives", "Medical Community", "Ukrainian Hygienic Society", "Ukrainian Medical Society"; in Sub Carpathian Russia - the House of Public Health; in Bukovyna - "Medical Council", which worked in the People's House in Chernivtsi; etc.). During 1919-1939, the Ukrainian Pedagogical Society "Ridna Shkola" (UPS), functioned in Galicia, actively joined the cause of 


\section{Інноватика у вихованні. Випуск 13.Том 2. 2021.}

preserving, strengthening and reproducing the health of the growing generation. The activities of the Ukrainian anti-alcohol and anti-nicotine societies "Renaissance" in Eastern Galicia and "Sobriety" in Sub Carpathian Russia were extraordinary: at the end of the $19^{\text {th }}$ - in the first third of the $20^{\text {th }}$ century. These organizations waged an «uncompromising» struggle for abstinence in public and private life, and called on all Ukrainian society to take various measures against alcohol and tobacco use (Slyvka, 2010, p. 280). The formation of practical skills of a healthy lifestyle in Ukrainians was included in the content of medical care courses initiated in the 30s of the twentieth century. "Women's community" in Bukovyna. For example, in February-April 1935, this organization permanently conducted hygiene and first aid courses in Chernivtsi in case of accidents. Among the institutions that focused on solving the problems of preserving and strengthening the health of the inhabitants of Sub Carpathian Russia was the TG Masaryk Anti-TB League. A prominent place in the activities of this organization was occupied by educational activities of relevant content in schools in the region, as evidenced, in particular, information about the establishment of clubs in schools called "Fight against tuberculosis" (Slyvka, 2013, pp. 134-135).

In the studied context we will mention public initiatives at the end of the $19^{\text {th }}$-at the beginning of the $20^{\text {th }}$ century on health promotion among the population of Poland. The large scale and systematic physical culture movement is connected first of all with the Sokil Gymnastics Society (in Polish: Towarzystwo Gimnastyczne , Sokót”), founded in 1866 in Lviv. The mission of the institution was to unite Polish youth around them in order to raise their national consciousness and improve their physical condition. Developing in many cities and towns of all regions of Poland, the falconry movement gained mass character and contributed to the promotion of physical culture and health activities, «awakened» sports interest among children and youth - they could practice in special halls and special areas of society (Dolata, 2016, p. 82). The brightest page in the implementation of extracurricular forms of physical culture and sports activities of children and youth in Poland was the most famous and longest project of Henryk Jordan (1842-1907) "Dr. Henryk Jordan City Park" in Krakow (in polish Park Miejski im. dra Henryka Jordana), which became the first in Europe in the late nineteenth century location of the "new" physical education (Morawska-Kleczkowska, 1959).

One of the public institutions involved in the health education of children and young people was the Health Care Society (in polish Towarzystwo Opieki Zdrowia). It was established in 1889 in Krakow. The main tasks of the organization were aimed at improving personal and public hygiene by organizing local departments in cities and towns under the slogan «Improving the material life of the people and their education can undoubtedly improve their health» (Żmichrowska, 2012, p. 13).

Quite representative in the context of the research topic are public initiatives for the organization of children's vacation camps in the fresh air to prevent disease and treat debilitated and frail children. Institutions of this format 


\section{Інноватика у вихованні. Випуск 13.Том 2. 2021.}

were first implemented in Switzerland in 1876 on the initiative of Pastor Hermann Walter Bion (1830-1909). The idea of children's holiday camps was brought to Poland by Stanislav Markievich (1839-1911). Cells of this type were called «summer colonies» (in polish kolonii letnie). In 1882, the Committee of Summer Colonies was established, and in April of the same year, with the support of charitable donations, the first camps for children aged 8 to 13 were organized (Dragański \& Żbikowski, 2011, s. 504). The "colonial" movement was quite popular later - in the Second Commonwealth. For example, in 1926, 50,000 participants went to summer camps, and in 1931, 133,000 children and young people rested there. During the interwar period of the $20^{\text {th }}$ century in Poland, semi-colonies (in polish półkolonia) were also actively organized recreational locations on the territories of schools or other sites adapted for this purpose within the urban space. They functioned in the tradition of the above-mentioned "Jordan Park", as well as "W. E. Raua Gardens" (in Polish "Ogrody im. W. E. Raua") - centers for games and entertainment, created in the late nineteenth century (Demel, 1972, s. 103).

And today, in the context of new global challenges, which, as never before, raise the issue of finding effective health initiatives, both Ukraine and the Republic of Poland continue to implement quite representative projects.

Worth noting is the project "Anti-addiction campaign against alcohol, tobacco and drugs among schoolchildren in Ivano-Frankivsk", which is organized for several years by the Ivano-Frankivsk district of NSOU "Plast" (Proekt, 2009). The aim of the project is to reduce the number of school-age children in rural areas who regularly drink alcohol and smoke, and are addicted to bad habits. The program of the project provides training of volunteers on the basics of promoting a healthy lifestyle and conducting anti-addiction seminars for students of Prykarpattia. A very interesting project was implemented in 2016 at the Vasyl Stefanyk Precarpathian National University. During two weeks, from May 18 to 31, 4th year students majoring in "Primary Education" carried out a series of activities under the general title "Youth - for a healthy lifestyle», which aimed to overcome the problem of smoking. The geography of the events covered various locations of the city of Ivano-Frankivsk, IvanoFrankivsk, Lviv and Zakarpattia regions. During the actions, young activists held hand-made posters "We are against smoking - we are a healthy generation", "Do not burn your future", "Your health is in your hands", "Do not smoke your health", "How long will you be able to live?", urged smokers to stop harming their health and the health of those around them, distributed health-preserving information materials, offered to exchange cigarettes for apples, candies and balloons. The final «chords» of the campaign were the collection of signatures from the leadership and teachers of the university to join the cohort of «opponents» of smoking and the exhibition of posters in the educational building of the Pedagogical Institute. As a result, fourth-year students unanimously recognized the need for and effectiveness of such actions, especially among the youth, which is the future of the nation (Studenty-pedagogy, 2016). 
Polish programs are original. Among them: "A glass of milk" (since 2004), "Keep fit" (since 2006), the National AIDS and HIV Prevention Program (since 2007), "Clean Air Around Us" (since 2008), "Fruits and vegetables at school" (since 2009), "Healthy eating and physical activity in schools" (since 2009), "Don't fall for me, please" (since 2010), etc. In order to construct appropriate health-preserving content, information materials included in the anti-tobacco health-saving education program "Run for Health" prepared by the General Sanitary Inspectorate of Poland (Bargiel-Matusiewicz \& Dziurla, 2016), the program "Safe Road to School", developed by the Polish Railway Transport Authority (Bezpieczna droga do szkoły, 2019), the program for safe use of Internet potential "Click with your head" (Klikam z głową, 2020), prepared by the Electronic Communications Department of Poland, etc. We believe that the programs we announced, with the organizational and financial support of public institutions, can be successfully implemented in Ukraine.

Conclusions and further research prospects. From all this, we can conclude that Ukraine and Poland have accumulated extensive experience in implementing educational programs of health content. Most of them are developed by state institutions, while public figures and organizations are involved in their implementation, and, to the extent possible, promote positive information about certain projects, provide financial support, etc., thus ensuring the continuity of health care. education of children and youth.

\section{СПИСОК ВИКОРИСТАНИХ ДЖЕРЕЛ}

Zdrowie i zachowania zdrowotne młodzieży szkolnej $w$ Polsce: na tle uwarunkowań socjodemograficznych: wyniki badań HBSC 2014. (2015). [pod. red. Joanny Mazur]. Warszawa: Instytut Matki i Dziecka. 276 s. URL: http://www.imid.med.pl/images/do-pobrania/Zdrowie_i_zachowania_ zdrowotne_www.pdf [Дата звернення 16.04.21].

Кондратюк, С. (2003). Інтегративний підхід до виховання у молодших школярів здорового способу життя. Кандидат педагогічних наук. Сумський державний педагогічний університет імені А. С. Макаренка.

Сливка, Л. (2010). Питання антиалкогольного виховання дітей i молоді у діяльності українських громадських товариств Західної України (1919-1939 рр.). Педагогічний альманах: Збірник наукових праџь. Х.: РІПО. Випуск 5. С. 278-284.

Сливка, Л. (2013). Виховання здорового способу життя молодших школярів (історичний та етнопедагогічний виміри): монографія. ІваноФранківськ: HAIP. 320 с.

Dolata, E. (2016). Galicyjscy popularyzatorzy zdrowia i higieny przełomu XIX i XX wieku. Lubelski Rocznik Pedagogiczny. T. XXXV. No 4. SS. 79-95.

Morawska-Kleczkowska, J. (1959). Doktor Henryk Jordan. Wiedza i Życie. Miesięcznik Popularno-Naukowy. nr. 8. SS. 504.

Żmichrowska, M. (2012). Działalność pedagogiczna Henryka Jordana (1842-1907). Prace Naukowe Wałbrzyskiej Wyżsej Szkoty Zarzązania $i$ Przedsiębiorczości. Zeszyty Pedagogiczno-Medyczne. nr. 18 (2). SS. 7-14. 
Dragański, K, Żbikowski, J. (2011). Spotkania z historią Polskiego Towarzystwa Higienicznego - dr Stanisław Markiewicz. Hygeia Public Health. 46(4). SS. 502-505.

Demel, M. (1972). Nauczyciel zdrowia. Życie i dzieło doktora Stanisława Kopczyńskiego. 1873 - 1933 - 1973. Warszawa: Nasza Księgarnia. $140 \mathrm{~s}$.

Проект "Антиузалежнююча кампанія проти вживання алкоголю, тютюну та наркотиків серед учнівської молоді». (2009). URL: http://www.if.gov.ua/news/8101. [Дата звернення 20.04.21].

Студенти-педагоги Прикарпатського університету провели «Протинікотинову акиію». (2016). URL: https:// firtka. if.ua / blog/ view/ studentipedagogi-prikarpatskogo-universitetu-proveli-protinikotinovu-akciufoto108207. [Дата звернення 20.04.21].

Bargiel-Matusiewicz, K., Dziurla, R. (2016). Program antytytoniowej edukacji zdrowotnej „Bieg po zdrowie”. Warszawa: Główny Inspektorat Sanitarny. $65 \mathrm{~s}$.

Bezpieczna droga do szkoty. (2019). URL: https://www.bezpiecznyprzejazd.pl/edukacja/dla-dzieci. [Дата звернення 20.04.21].

Klikam z głowa. (2020). URL: https://cik.uke.gov.pl/news/poradnik-dlanauczycieli-i-rodzicow,228.html. [Дата звернення 18.04.21].

\section{REFERENCES}

Zdrovye $i$ zachovanya zdrovotne mlodziezhy shkolnej $v$ Polsce: na tle uvarunkowan socyodemografichnych: vyniki badan HBSC 2014 [Health and health behavior of schoolchildren in Poland: against the background of sociodemographic conditions: the results of HBSC research 2014]. (2015). [pod. red. Joanny Mazur]. Warszawa: Instytut Matki i Dziecka. 276 s. URL: http://www.imid.med.pl/images/do-pobrania/Zdrowie_i_zachowania_zdrowotn _www.pdf. [Data zvernennia 16.04.21]. [in Polish].

Kondratiuk, S. (2003). Integratyvny pidchid do vychovannya u molodszych shkolyariv zdorovogo sposobu zhyttya [An integrative approach to educating younger students in a healthy lifestyle]: Kandydqt pedahohichnykh nauk. Sumskyi derzhavnyi pedahohichnyi universytet imeni A. S. Makarenka. [in Ukrainian].

Slyvka, L. (2010). Pytannya antyalkogolnogo vychovannya ditey ta molodi u diyalnosti ukrainskich gromadskich tovarystv Zachidnoyi Ukrainy (1919 1939 pp.) [Issues of anti-alcohol education of children and youth in the activities of Ukrainian public societies in Western Ukraine (1919-1939)]. Pedagogichny almanach: Zbirnyk naukovych prac. Vypusk 5. P. 278-284. [in Ukrainian].

Slyvka, L. (2013). Vychovannia zdorovoho sposobu zhyttia molodshykh shkoliariv (istorychni ta etnipedagogichni vymiry): monografija [Education of a healthy way of life of junior schoolchildren (historical and ethnopedagogical dimensions): monograph]. Iv.-Fr.: NAIR. 320 p. [in Ukrainian].

Dolata, E. (2016). Galicyyscy popularyzatozhy zdrovya i higieny pshelomu XIX i XX vieku [Galician popularizers of health and hygiene at the 


\section{Інноватика у вихованні. Випуск 13.Том 2. 2021.}

turn of the XIX and XX centuries]. Lubelski Rochnik Pedagogichny. T. XXXV. No 4. SS. 79-95 [in Polish].

Moravska-Klechkovska, J. (1959). Doktor Henryk Yordan [Dr. Henryk Jordan]. Viedza i Zhycie. Miesenchnik Popularno-Naukovy. nr. 8. P. 504 [in Polish].

Zhmichrovska, M. (2012). Dzialalnoshch pedagogichna Henryka Yordana (1842-1907) [Pedagogical activity of Henryk Jordan (1842-1907)]. Prace Naukove Valbzhyskyey Vyzhshey Shkoly Zazhondzanya $i$ Pshedshembiorchoshchi. Zeshyty Pedagogichno-Medychne. nr. 18 (2). PP. 7-14 [in Polish].

Draganski, K, Zhbikovski, Y. (2011). Spotkanya z historiyo Polskyego Tovazhystva Higyenichnego - dr Stanislav Markyevich [Meetings with the history of the Polish Hygienic Society - Dr. Stanislav Markievich]. Hygeia Public Health. 46(4). PP. 502-505. [in Polish].

Demel, M. (1972). Nauchychyel zdrovia. Zhychye $i$ dzielo doktora Stanislava Kopchynskyego. 1873 - 1933 - 1973 [Health teacher. Life and work of doctor Stanislav Kopchynski. 1873-1933-1973]. Warszawa: Our bookstore. 140 p. [in Polish].

Proekt "Antyuzalezhnyuyucha kampaniya proty vzhyvannia alkogolyu, tyutyunuta narkotykiv sered uchnivskoyi molodi" ["Anti-addiction campaign against alcohol, tobacco and drug use among student youth"]. (2009). URL: http://www.if.gov.ua/news/8101. [Data zvernennia: 20.04. 2021]. [in Ukrainian].

Studenty-pedahohy Prykarpatskoho universytetu provely "Protynikotynovu aktsiyu" [Students-teachers of Prycarpathian University organized an "Anti-nicotine action”]. (2016). URL: https://firtka.if.ua/blog/ view/studentipedagogi-prikarpatskogo-universitetu-proveli-protinikotinovuakciu-foto108207. [Data zvernennia 20.04. 21]. [in Ukrainian].

Bargiel-Matusievich, K., Dziurla, R. (2016). Program antytytoniovej edukatsyi zdrovotnej "Byeg po zdrovye" [Anti-tobacco health education program "Health Run". Warszawa: Chief Sanitary Inspectorate. 65 p. [in Polish].

Bezpyechna droga do shkoly [Safe way to school]. (2019). URL: https://www.bezpieczny-przejazd.pl/edukacja/dla-dzieci. [Data zvernennia 20.04. 21]. [in Polish].

Klikam z glovou [I click with my head]. (2020). URL: https://cik.uke.gov.pl/news/poradnik-dla-nauczycieli-i-rodzicow,228.html.

[Data zvernennia 18.04. 21]. [in Polish].

\section{ГРОМАДСЬКІ ІНЦЦАТИВИ У РЕАЛІЗАЦЇ̈ ВИХОВНИХ ПРОГРАМ ЗДОРОВ'ЯЗБЕРЕЖУВАЛЬНОГО ЗМІСТУ: УКРАЇНСЫКИЙ ТА ПОЛЬСЬКИЙ ДОСВІД}

Сливка Лариса кандидат педагогічних наук, доцент кафедри педагогіки початкової освіти 


\section{Інноватика у вихованні. Випуск 13.Том 2. 2021.}

Прикарпатського національного університету імені Василя Стефаника,

м. Івано-Франківськ, Україна ORCID: 0000-0003-1865-6326 e-mail:loroczka@ukr.net

Котурбаш Наталія здобувач вищої освіти другого ступеня «магістр» спеціальності «Початкова освіта» Прикарпатського національного університету імені Василя Стефаника, м. Івано-Франківськ, Україна ORCID: 0000-0002-4654-6274 e-mail: nataliia.koturbash@pnu.edu.ua

Анотація. У статті здійснено спробу проведення аналізу щодо практики реалізації в Україні та Польщі деяких виховних програм, спрямованих на формування здорового способу життя дітей та молоді, зокрема ролі у цьому процесі громадських активістів та організацій. Зазначено, що важливою умовою ефективності здоров'язбережувальних виховних впливів $є$ безперервність цього процесу і виявляється вона у доцільній взаємодії педагогів, психологів, батьків, медичних працівників та освітніх і позашкільних виховних закладів, родинного середовища, культурно-освітніх установ, дитячо-юнацьких об'єднань, громадських організацій ін.

Анотативно охарактеризовано діяльність громадських організацій і товариств, які в 1920-х - 1930-х рр. здійснювали здоров'язбережувальну діяльність на теренах Західної України. Репрезентовано польські інституції, які наприкінці XIX - на початку XX ст. стояли у фарватері громадського руху щодо промоції здоров'я серед населення.

Згадано про два здоров'язбережувальні проєкти, які реалізувалися в сучасній Україні: «Антиузалежнююча кампанія проти вживання алкоголю, тютюну та наркотиків серед шкільної молоді м. Івано-Франківська» (2009) i «Юнацтво - за здоровий спосіб життя» (2016). Представлено перелік польських навчально-виховних програм, в яких представлено розмаїтий здоров'язбережувальний контент («Склянка молока», «Тримай форму», «Чисте повітря навколо нас», «Фрукти і овочі у школі», «Здорове харчування і фізична активність у школах», «Не пали при мені, будьласка», «Біг по здоров'я», «Безпечна дорога до школи»). Зазначено, що громадські діячі і організації сприяють поширенню позитивної інформації про ті чи інші проєкти, надають фінансову підтримку, забезпечуючи тим самим безперервність здоров'язбережувального виховання дітей та молоді.

Keywords: здоров'язбережувальне виховання, виховні програми, громадська діяльність, Україна, Польща.

Стаття надійшла до редакиії 07.05.2021 p. 